\title{
Scientific Exchange
}

FRED R. CAGLE, Ph.D.

Specific steps for strengthening American science in relation to science in the U.S.S.R. are advocated by Professor Fred Cagle, chairman of the department of zoology, Tulane University, after 40 days of consultations with scientists in research institutes in the Soviet Union. Cagle visited Soviet centers in behalf of the American Institute of Biological Sciences. The following text is based upon informal remarks by Cagle in Washington, D.C., December 17, 1958. A formal report of this mission was published in the Bulletin of the American Institute of Biological Sciences, January 1959, pp. 16-20.

AFER intense preparations, I went to A Russia confident that I knew a great deal about the country. I returned aware mainly of my vast ignorance. As a scientist, what I learned was gratifying. As an American, I also found it frightening.

'Although in many respects Russian biological sciences are less advanced than ours, the rate of progress is such that in a few years ours can easily be surpassed.

\section{Science Carries Weight}

I was particularly impressed with the influence that scientists enjoy in their government. Many of them have a status and responsibility comparable to that of a Senator or Congressman in this country. One of the botanists I met impressed me particularly by the intelligence of her questions about America. For this reason, I inquired about her and learned that she was a deputy president of one chamber of the Supreme Soviet.

Scientists, I was told, do not merely advise or recommend but actually plan the studies which should be carried on in connection with such public projects as, say, a new reservoir. And in pursuing such studies, which aim primarily at practical applications, as does most Soviet science, it appears that they also provide for basic research. Like us, Soviet scientists wish to answer fundamental questions as well as the immediate ones.

\section{Eager to Exchange}

Soviet scientists are eager for us to know what they are doing. Repeatedly they expressed irritation to me because we do not read their literature. Although they do not understand why we do not learn Russian, they have published many of their papers with both Russian and English titles and with abstracts or summaries in English. With some encouragement from us, they would certainly do more to make their papers available in English.

They tend to publish their more valuable papers as monographs, for which they are well paid, rather than in serial journals. So it becomes necessary for us to learn not only what is available in their literature but also how to appraise it. Several scientists expressed amazement that we had bothered to translate some of the Russian works which we have put into English, and on the other hand they could not understand why we had ignored certain important biological studies.

\section{Ignorance of America}

Learned though they are in their sciences, the Soviet scholars are remarkably ill-informed about American scientific institutions and their operations. To illustrate the contrasting customs: When an American requests a Russian publication from a Soviet scientist, the book is procured and mailed at government expense; but when a Russian puts such a request to an American university professor, the book is sent as a courtesy, often at considerable personal expense. 
In this country, most biological research is conducted in universities as an adjunct of teaching; the Soviets conduct most research in research institutions. Here, when an investigator assumes administrative or political duties, he usually discontinues scholarly research. In the Soviet research institutions, it is assumed that the administrative directors will continue their studies and that facilities will be provided to the extent they are available. For example, Pavlovsky, the father of Russian zoology, continues to publish reports of his new research although he has many official duties and is well advanced in years.

It is almost impossible for a Soviet scientist to comprehend the character of an American university or the procedures by which our research is financed. When I told my hosts that Tulane was a private institution, they assumed it was dedicated to profits, or that it returned a profit to the people who financed it, or that, since it was supported by gifts, it was a charity school for the poor.

Their ignorance of American institutions appeared to be a product of their specialized education, rather than a lack of curiosity or freedom of inquiry. So far as I could observe, they seemed relaxed in their attitudes and were willing to discuss any subject. Despite such events as Pasternak's refusal of the Nobel Prize, they appear to feel we exaggerate conditions there. Among the men I met was a geneticist who told me with some scorn that he was one of several reported by the American press as liquidated for opposition to Lysenko. During the period of his supposed suppression, he said he had published several major papers on genetics.

I was also assured repeatedly that Communist Party membership is not a factor in determining promotions in research institutes. A candidate, the term used for a predoctoral worker, is at first assigned duties according to the needs of his supervisors, but as he demonstrates a capacity for original investigation, he is given free rein and promotions according to the professional appraisal by his colleagues. On the other hand, on an occasion when I was admonishing my hosts that scientists must not behave like politicians, I was told that nearly half of the scientists in the immediate gathering were members of the Communist Party. "We are not like politicians," my informant emphasized. "We are politicians."

\section{Opportunities for Research}

Research academies of the constituent Republics of the Soviet Union appear to be free to develop their own programs. They are not subordinate to the All-Union Academy, but the work of all academies is coordinated by a separate council. I am under the impression that each Republic finances its own research institutes and that they are under no other restraint as to the direction of their activities.

The institutions were adequately but not élaborately equipped. One celebrated institution I visited at Irkutsk on Lake Baikal is housed in a small wooden structure, with cubbyholes for individual investigators. In construction at this station, however, is a collection of brick buildings, scheduled for completion next year, to house the International Limnological Institute. One of the buildings is a dormitory planned for the use of scientists from other lands. Directors of the institute said they would like to have Americans and others come to work there for 6-month terms.

Typically, it did not occur to the Soviet scientists that an American might find it difficult to raise the money for such a stay. They are not even aware that some Americans have found it difficult to travel as they wish in the U.S.S.R., although they do know and deeply resent restrictions that have been placed on Soviet visitors to the United States. Their resentment is the stronger because many wish to come here on scientific missions.

\section{Conclusions}

From my conversations and observations, it appears that if we continue to expand present programs to send well-informed scientists from the United States for consultation with their Soviet colleagues, they would certainly be effective in improving Soviet understanding and respect for this country. Moreover, since the Soviet scientist has a direct voice in government decisions, the influence of American visitors could come to be felt in the highest political circles. It is recognized that such visitors need 
to be well informed, and should be well briefed in advance. I found also it was quite helpful to have personal letters of introduction wherever I visited. As many Russians speak English, the language barrier is not overwhelming, but it is nevertheless an incalculable asset for the visitor to know the language of the host country, if only as a matter of good will.

Another means we may use to inform Soviet scientists about the United States is to publish, in our scientific journals, essays which comment upon and explain some of the complexities of our society. We can also expand our exchange of journals. The scientific libraries of the various Republics are usually inadequate and they would like to exchange with us. It would not be difficult to prepare a list of libraries which wish to share in such an exchange.

To encourage the publication in English of abstracts of Russian papers, we might reciprocate by publishing Russian language abstracts of important American contributions. We also need to make a more systematic effort to study, appraise, and collect Russian biological literature, as a phase of the current Russian translation program.

In my judgment, we should send more biologists to work in the U.S.S.R. At present there is only one biologist on the staff of our Embassy in Moscow. Strong representation there, I feel, could do much to inform Soviet scientists about American scientists and their work.

\section{Results of a Survey on Hearing Loss in Children}

Only 15 to 20 percent of the school children with known hearing losses are receiving any kind of educational help, according to the findings of the Committee for Hearing Conservation, American Public Health Association.

The committee, after $3 \frac{1}{2}$ years of study, conservatively estimates that 5 percent $(1,790$,176) of the total school population would fail group hearing tests, and, of these, 39 percent $(698,168)$ would be expected to have true hearing losses.

The study, which was co-sponsored by the American School Health Association, covered 1,362 communities in 48 States. Of these communities, 39 administered only one test during the school life of their children, and 7 of these did not begin testing until the seventh grade. Another 15 communities, which gave two or three tests, also began testing in the seventh grade or later. Yet research clearly indicates that the best preventive work is done when hearing losses are detected early and referred for medical help. By the time a child reaches the seventh grade, hearing loss may be irreversible. Furthermore, if irreversible cases are found early enough, proper education and treatment would promote better adjustment and learning.

The study also revealed that there is no uniform program in the United States for detecting hearing losses in school children. Some areas have a program that is considered very satisfactory, but others have no program at all.

Moreover, there is no uniformity in the criteria used in determining failure on any of the audiometric tests, in the administration of tests, in referral for treatment, in notifying parents, or in the kind of treatment and education given.

Dr. C. Adele Brown, chairman of the Committee for Hearing Conservation, and director of school health services, Oswego, N.Y., reported these findings. Other members of the committee were Dr. L. M. DiCarlo, Dr. I. P. Barrett, Dr. M. E. Doster, Dr. C. D. O'Connor, Dr. C. N. Brownsberger, Dr. A. Yankauer, and T. J. LePine. 